\title{
Interlingual Pronoun Errors in English-Arabic Translation
}

\author{
Reima Sado Al-Jarf \\ King Saud University
}

\begin{abstract}
Unlike English, Standard Arabic has two forms of subject pronouns: Independent such as ?na (I), and a pronominal suffix that is an integral part of the verb such as katab-tu (I wrote). Independent subject pronouns are commonly used in nominal sentences, not verbal sentences. Use of independent subject pronouns in verbal statements depends on syntactic, pragmatic, discoursal and semantic factors available in a particular context. The present study investigates translation students' awareness of the syntactic, pragmatic and discoursal restrictions that determine the use of Arabic subject pronouns when translating connected discourse from English into Arabic. An error corpus of faulty uses of Arabic independent subject pronouns was collected from the translation projects of senior students majoring in translation. Syntactic, pragmatic and discoursal criteria were used to judge the deviations. It was found that students translate imitatively rather than discriminately. Since English sentences begin with a subject pronoun such as $I$, he, they, the students used an independent subject pronoun followed by a verb + pronominal suffix in declarative, affirmative statement, without realizing that the subject is contained in the verb, and use of ?na or huwa is redundant. Implications for increasing students' awareness of pragmatic, discoursal and syntactic constraints in translating English pronouns into Arabic are provided.
\end{abstract}

\section{Introduction}

Errors are an indispensable part of language learning and learning to translate. They result from two psychological processes: transfer and simplification (Arabski, 1979). Numerous 
researchers have examined pronoun errors made by language learners and student translators. For instance, Moore (2001) found that the children with expressive specific language impairment (SLI) produced more errors with third person singular (3Psg) pronouns than did their age-level peers, but they did not make more errors than their MLU-matched peers. Error patterns were similar in the children with specific language impairment (SLI) and their language-level peers. The most frequent type of error was the substitution of the objective case for the nominative case. More errors were made on the feminine pronoun, she, than on the masculine pronoun, he. In another study, Anton-Mendez (2010) studied pronoun errors of Spanish and French speakers of L2 English. The researcher found that Spanish speakers produced significantly more gender errors than any other type of pronoun error, and significantly more gender errors than French speakers as Spanish is a pro-drop language where many sentences do not require gender to be encoded had they been uttered in L1 instead of L2. Some L2 pronoun error such as "he/she" confusions, by Spanish speakers of L2 English, could be due to differences in the information requirements of the speakers' two languages, providing a window into the composition of the preverbal message that guides grammatical encoding during language production.

In translation, Künzli (2009) collected process and product data from 20 trainee and professional translators who were asked to translate a text or revise a draft translation while thinking aloud. The analysis of the Swedish target texts revealed both inter-individual variation in the choice of the address pronoun, and intra-individual variation showing inconsistent address use. Choice of the appropriate address pronoun was found to constitute a problem in French-Swedish translation. Likewise, in English-Romanian translation, a special problem is posed by the pronoun "you," which has many forms. In Romanian there are distinct forms of the second persons pronoun has distinct forms that are used in parallel with forms of the pronoun of reverence, which permits a wide gradation in communicating the 
message. Therefore, when translating from English, a wider context is necessary to help the translator understand the nature of the relations between the addressor and addressee. For instance, in translating from English into Romanian, personal pronouns usage peculiarities must be kept in mind. It is unnecessary to render all the personal pronouns as this would produce clumsy translations, since in Romanian use of personal pronoun is a means of accentuation (Iliescu, 1972).

A review of the literature revealed several interpretations of the sources of pronoun errors in language acquisition and translation. For example, Sorace \& Serratrice (2009) compared the performance of English- Italian and Spanish-Italian bilingual children, monolingual English and Italian-speaking children and adults on forced-choice grammaticality tasks on the distribution of overt and null subject pronouns in Italian and in English. They found that processing factors play a non-trivial role in the difficulty encountered by bilinguals in coordinating syntax with contextual discourse-pragmatic information, regardless of the presence or absence of partial structural overlap. In the case of the internal coordination between syntax and semantics, processing factors may be less likely to affect bilinguals' performance, while the extent of structural overlap and the associated internal formal features seem to play a more important role.

A review of prior studies has also shown a lack of research that focuses on errors committed by adult learners in Arabic independent subject pronouns in second language acquisition and translation. Therefore the present intends to fill a gap in this area and investigate translation students' awareness of the syntactic, pragmatic and discoursal restrictions that determine the use of Arabic independent subject pronouns when translating connected discourse from English into Modern Standard Arabic (MSA). It attempts to describe the nature, frequency and possible sources of faulty uses of independent subject pronouns in the translation of texts from English into MSA by advance college students 
majoring in translation at the College of Languages and Translation (COLT) and examine the syntactic environments in which deviant uses of Arabic independent subject pronouns occurred and the strategies student translators used in their errors.

Examination of faulty uses of Arabic independent subject pronouns is intended to reveal students' weaknesses, the processes student translators employ in translating subject pronouns, and the factors that influence their language-switching behavior and thinking processes. It will shed some light on their awareness of subject pronouns differences between English and Arabic. Awareness of the deviant paths of translation may disclose neglected areas of translation teaching and theory and will be helpful in planning translation instruction.

\section{Uses of Independent Subject Pronouns in MSA}

Modern Standard Arabic (MSA) has two forms of subject pronouns: An independent detached form (See examples in Table 1); and an attached form, i.e. a clitic pronoun or a pronominal affix depending on the verb tense) which is an integral part of the verb (see examples in Table 2).

Table 1: Independent Subject Pronouns in MSA

\begin{tabular}{|l|l|}
\hline ?na (I) & ?antunna (you -fem - sing) \\
\hline nahnu (we) & huwa (he) \\
\hline ?nta (you - mas - sing) & hiya (she) \\
\hline ?anti (you - fem - sing) & huma (they - dual) \\
\hline ?ntuma (you - dual ) & hum (they - mas $-\mathrm{pl})$ \\
\hline ?amtum (you - mas - pl) & hunna (they - fem - pl) \\
\hline
\end{tabular}


Table 2: Subject Pronominal Affixes (Clitic Pronouns)

\begin{tabular}{|l|l|}
\hline \multicolumn{1}{|c|}{ With Past Tense verbs } & \multicolumn{1}{|c|}{ With Present Tense Verbs } \\
\hline katab + tu (wrote - i) & ?a + ktub (i -write) \\
\hline katab + na (wrote - we) & na + ktub (we -write) \\
\hline katab + ta (wrote -you-sing-mas) & ta-ktubu (you-write-sing-mas) \\
\hline kataba + ti (wrote -you-sing-fem) & ta-ktub-iyn (you-write -sing-fem) \\
\hline katab-aa (they-dual) & tak-tub-aan (you-write - dual) \\
\hline katab-uw (they-pl-mas) & ta-ktubu -uwn (you-write - pl-mas) \\
\hline katab-tum (they-pl-fem) & ta-ktub-na (you-write -pl-fem) \\
\hline kataba (he wrote) & ya-ktubu (he writes) \\
\hline kataba- t (wrote - she) & ta-ktubu (she- writes) \\
\hline kataba (wrote -he) & ya-ktub-na (they-write- pl-fem) \\
\hline katab-na (wrote - they- pl-fem) & \\
\hline
\end{tabular}

Independent subject pronouns are commonly used in nominal sentences, not verbal sentences. Use of independent subject pronouns in verbal statements depends on syntactic, pragmatic, discoursal and semantic factors available in a particular context. According to Ryding (2005), independent personal subject pronouns in MSA have the following functions:

1. To emphasize the subject of a verb as in:

He is the one who did it. هو الذي فعل زللك

2. Subject of an equational sentence as in: 
He is an expert on the Middle East. هو خبير في شئون الثرق الاوسط

3. Predicate of an equational sentence as in:

هذا هو .Here he is

4. As a copula as in:

The Rhine is the longest river in Europe. ونكر الرابن هو أهم نهر في اوروبا

Unlike English, Arabic is a "pro-drop" language. This feature results in the verb inflectional paradigm distinguishing all persons uniquely. Pro-drop is applied in discourseneutral word order. Independent subject pronouns give emphasis to the subject. Pragmatic, discoursal, stylistic, syntactic factors that affect the use of independent subject pronouns include implied contrast and new information, introducing a discourse topic, discourse structure and organization of information. Subject, theme and agent do not tend to coincide in expository, descriptive or instructional discourse.

\section{Subjects}

46 senior female students majoring in translation at the College of Languages and Translation (COLT), King Saud University, Riyadh, Saudi Arabia participated in the study. All the subjects were native speakers of Arabic. They all had completed courses in EFL (66 hours), linguistics, semantics, text linguistics and stylistics (11 hours), interpreting (15 hours), written translation in 18 subject areas (36 hours), target culture (7 hours), and Arabic Syntax and morphology (18 hours).

\section{Data Collection and Analysis}

A corpus of 429 faulty uses of Arabic independent personal subject pronouns was collected from the translation projects of senior students majoring in translation at COLT. Errors were collected from the first translation of the source text. Deviant uses of independent subject pronouns were defined as instances in which an independent subject pronoun was incorrectly 
inserted in verbal sentences, although the context is neutral, no emphasis is placed on the subjects and there is no implied contrast. The data were judged to be deviant in relation to the context in which they occurred. Judgments of deviations were based on syntactic, stylistic and pragmatic criteria. Deviant use of independent subject pronouns was submitted to a panel of 3 professors of Arabic to verify the error data.

Corpus analysis started by highlighting the independent subject pronouns which were incorrectly inserted before the verbs. Each error was then classified as being interlingual, i.e., due to transfer from English, or intralingual, i.e., due to inadequate competence in Arabic. Intralingual errors covered instances where the students failed to identify the syntactic, pragmatic, discoursal and semantic conditions that require use of an independent subject pronoun in verbal sentences. In those cases, use of an independent subject pronoun was not motivated by implied contrast, introduction of a topic of discourse, organization of information, genre, focus and theme. Independent subject pronouns that are semantically deviant are those where the communicative intention of the speech act, the speaker's emotional state, and the theme-rheme composition do not require an use of any independent subject pronouns. Syntactic errors are those in which a grammatical rule is violated. The syntactic contexts (environments) in which an independent subject pronoun was incorrectly inserted before the verb included the type of sentence where the deviations occurred (Simple, Compound, Complex). Avoidance strategies utilized by the students in this study were also identified. Avoidance strategies refer to those structures used to place an independent subject pronoun before the verb instead of using a pro-drop structure. Performance errors due to memory limitations, fatigue and the like were excluded. Percentages of errors in each category and inter-analyst reliability were calculated. 


\section{Results and discussion}

Analysis of the error corpus has shown that all of the faulty independent subject pronouns occurred in statements and in expository, descriptive discourse which aimed at providing information about the topic of the articles. No pragmatic or discoursal reasons for using independent subject pronouns are available. The contexts in which faulty independent subject pronouns were used were neutral and contained no contrast, no emphasis, no introduction of new information or discourse topic was introduced. The discourse structure and organization of information did not require use of independent subject pronouns (See examples 1-6).

(1) The Rhine is the longest river in Germany. It originates in the Swiss Alps in the middle of Switzerland and flows north and east approximately 820 miles

Wa-nahr-u rrayn ?ahammu nahr-in fiy uwruppa, wa-huwa yanbu3u min jibaal lil-?alb fiy wasaT swiysra.

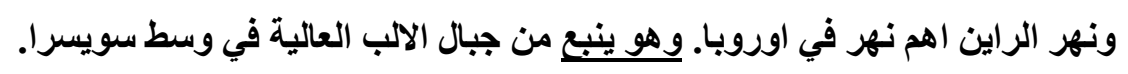

(2) Among the four major German rivers, the Weser River lies entirely within Germany. It originates in the middle hilly region and enters the North Sea in the southernmost part of the German Bight.

wa-min bayn-il ?nhar-il ?almaniyya l?arba3a, yu-3add-u nahru fizer ?annahra l-waHiyd ?allaTHiy huwa ?almaniy bi-kamilihi, wa-huwa ya-nbu3-u minal hiDabil wusTaa...

ومن بين الانهار الالمانية الاربعة الرئيسة يعد نهر فيزر النهر الوحيد الذي هو الماني بكامله. وهو ينبع من الهضاب

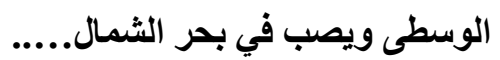

(3) A third coalfield is located in west Germany near Aachen and lies in Holland, Belgium and north France. It contains anthracite, a fine type of coal as well. 
Wa-hunaaka Haqlun THaliTHun ya-qa3-u fiy ?aqsaa Garb ?almanya bilgurbi min madiynati aaXin, // wa-yamtadd-u fiy holandaa ,baljiyka wa Samaal faransaa, wa-huwa yaHtawi_3alaa faHm anTHrasiyt....

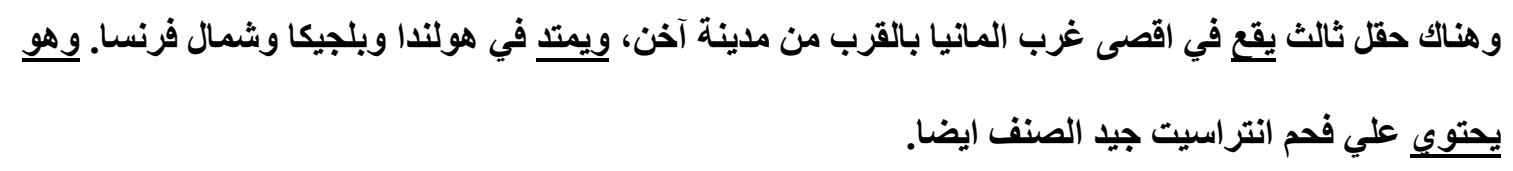

(4) In general, the Bundestag is elected directly from 299 constituencies. It has 874 members of which 22 members represent from West Berlin.

wa-ya-timmu ntiXaabu majlisu nnuwwabi .......wa-huwa ya-Dumm-u 874 3uDwan .....

ويتِ انتخاب مجلس النواب بتصويت عام حر مباشر .... ، وهو يضد 874 عضواً ، منهم 22 عضواً لبرلين الغربية.

(5) Oil is forced out into reservoir rocks, which occur in the same general region as the source rock.

yu-dfa2-u nnafTu ?ilaa suXuwril mustawda3, wa-llatiy ya-timmu DDaGT-u nnafTi daXilahaa, wa-hiya ta-tawajad-u fiy nafsil minTaqa llatiy tu-wjad-u fiyha suxuwrul mansha?

يدفع النفط الى صخور المستودع والتي يتِ ضغط النفط داخلها وهي تتواجد في نفس المنطقة التي توجد فيها صخور المنشأ.

(6) This means that the moon looks different from one night to the next. The moon appears to change shape and we call these changes the phases of the moon. wa-haDHaa yaßniy ?anna lqamara ya?xuDHu ?shkalan muztalifatan fiy kulli laylatin. wa-huwa yamurru bi-maraHila yataGayyaru fiyhaa shakluhu....

وهذا يعني أن القمر يأخذ أشكالا مختلفة في كل ليلة. وهو يمير بمراحل يتغير فيها شكله وتدعى هذه المراحل بفترات 
A second result was that students in the present study tended to use third person singular pronouns (he \& she; huwa \& hiya). No other independent subject pronouns were used in the error data, probably because the types of texts they translated did not include any other pronouns. In example (5) above, even the relative pronoun 'which' in the source text was translated into an independent personal pronoun rather than an equivalent Arabic relative pronoun. The explicit subject 'The moon' in the English source text in example (6) was also substituted by an independent pronoun in the Arabic target text.

A third result was that faulty independent subject pronouns occurred in long stretches of discourse, containing compound sentences, each consisting of two or more independent clauses requiring a parallel structure. Since the first clause in each compound sentence is verbal, the second and third clauses should be parallel, i.e. should be verbal sentences, in which case insertion of an independent subject pronoun before the verb in the second or third clause is grammatically incorrect, although it does not affect comprehension of the translated sentence. Parallel structure between the 2 clauses was not noted; both clauses of the compound sentence should contain a verb + pronominal affix. A verb + pronominal affix was used in the first clause but a particle + independent subject pronoun + verb + pronominal affix was used in the second clause.

A fourth results is that students in the present study avoided pro-drop in the Arabic target text, as in examples 1-6 above. To impose the independent subject pronoun before the verb, a particle such as ' $w a$ ' (and) or ' $f a$ ' (a particle showing succession) was attached to the pronoun.

Examination of the errors data also indicated that the sources of independent subject pronoun errors are both intralingual and iterlingual, i.e., they are intralingual as they reflect students' unawareness of the Arabic syntactic rule for independent pro-drop in verbal sentences and clauses. The students did not pay attention to the type and structure of clauses 
making up compound sentences and whether all clauses should have a verb + pronominal affix. The same errors are interlingual because the students just transferred the English (L2) word order which requires use of a subject pronoun in all sentences to Arabic (L1). In these errors the participants seemed to translate imitatively rather than discriminately. Since English sentences begin with a subject pronoun such as 'It', the students used an independent subject pronoun followed by a verb + pronominal affix in declarative, affirmative statement, without realizing that the subject is contained in the verb, and use of huwa or hiya as a subject is redundant. They even overgeneralized the use of the independent subject pronouns in examples such as $5 \& 6$ when the relative pronoun 'which' and the subject noun 'the moon' were replaced by an independent personal pronoun.

Findings of the present study, in which students imposed the English subject pronoun system on Arabic verbal sentences when translating English expository texts into Arabic, are partially consistent with findings of a study by Godin (1982) and inconsistent with findings of other studies by Tadros (1979), Noor (1996), Yuan and Zhao (2005) and others on pronoun acquisition in second language learning, in which second language learners, in general, and Arab learners, in particular, transferred their L1 pronoun system to L2. In Godin's study (1982), 50\% of the errors made by French-speaking students learning English were due to interlingual causes and 50\% had their source within the target language itself. Negative transfer was an important source of errors and overgeneralization seemed to be the most common cause. Godin also noted that some errors persist on all levels even after many years of study. In Tadros' study (1979), Sudanese students directly transferred the relative pronouns plus personal pronouns structure from Arabic to English instead of using the English structure consisting of a relative pronoun only in their writing. In addition, in processing English syntactic structures, native Arabic-speaking learners of English as a second language adopted certain strategies similar to those of first-language learners, 
including simplification and overgeneralization (Noor, 1996). When acquisition of Chinese resumptive pronouns (RPs) by advanced Palestinian Arabic-speaking learners of Chinese and intermediate English-speaking learners of Chinese was compared, both groups of students made similar errors, although Palestinian Arabic speakers were more advanced learners of Chinese than the English speakers and use of resumptive pronouns (RPs) is available in Palestinian Arabic but not in English. Errors accounted for the difference between the two groups on the basis of L1 transfer in addition to learnability problems (Yuan and Zhao, 2005).

Independent pronoun errors made by translation students in the present study can be explained in the light of several theories that were used in prior studies to explain pronoun errors committed by children and adults in second language acquisition and translation. Rothman (2009) indicated that deficits at the syntax-pragmatics interface cause what appears to be particular non-target-like syntactic behavior in L2 performance. The syntax-beforediscourse hypothesis was examined by analyzing null vs. overt subject pronoun distribution in L2 Spanish by English L1 learners. As ultimately determined by L2 knowledge of the Overt Pronoun Constraint (Montalbetti, 1984), the data indicate that L2 learners at the intermediate and advanced levels reset the Null Subject Parameter, but only advanced learners have acquired a more or less target null/overt subject distribution. Rothman (2009) found an overuse of both overt and null subject pronouns. As a result, this behavior cannot be from L1 interference alone as interface-conditioned properties are more complex and therefore, harder to acquire.

The null vs. overt subject pronouns in Spanish are equivalent to pro-drop and independent personal subject pronoun use in MSA. Like English native speaking students learning Spanish as L2, students translating from English into Arabic lacked knowledge of 
the distribution of pro-drop and independent personal subject pronoun use in MSA due to deficits at the syntax-pragmatics interface.

Furthermore, independent pronoun errors made by translation students in the present study can be explained by the Surface Hypothesis developed by Leonard (1989) which offers an explanation of language impairment (LI) based on profiles of linguistic characteristics of children with SLI. That profile includes moderate deficits in lexical and syntactic areas but more severe deficits in the area of grammatical morphology. Findings of the present study revealed translation students inadequate syntactic competence in the assignment of independent subject pronouns in L1.

Finally, overgeneralization of the third person independent subject pronouns in the error data is consistent with findings of studies by Rispoli $(2005,1998 \mathrm{a}, 1989 \mathrm{~b}, 1992)$ and can be explained in the light of the same pronoun paradigm building hypothesis (PPBH). Rispoli indicated that when pronoun paradigm building outstrips the development of INFL, children become especially vulnerable to erring in the choice of pronominal word form, resulting in pronoun case error. But when pronoun paradigm building proceeds more conservatively, the risk of error is reduced. His data showed that pronoun case error was minimal among children who had strong INFL. However, among children with weak INFL there was a wide range of variation, some children making many errors and others making none. These findings show that pronoun case errors are not an inevitable result of grammatical development, but may conceivably be avoided altogether if paradigm building proceeds at a rate commensurate with the child's development of INFL.

The PPBH model also provides explanations for the different error patterns in young children during developing stages. The PPBH predicts that nominative case errors will occur more frequently than objective case errors. Further, the distribution of errors across the two nominative pronouns (he, she) will not be equal. Specifically, PPBH predicts a greater 
likelihood of errors of substitutions of her for she than substitutions of him for he. This error pattern is due to the double appearance of the pronoun her in the pronoun paradigm. The form her appears in the matrix under both objective and genitive (possessive). He called this double appearance a "double cell effect." This situation serves to increase the retrieval strength of the word form her. In his study, Rispoli (1998) found that the children made more substitutions of her for she than the substitutions of him for he.

Similarly, translation students in the present study made more independent subject pronoun errors and almost no independent object pronoun errors. According to $\mathrm{PPBH}$, the assignment of Arabic independent subject pronouns in verbal sentences can be reduced if translation students' awareness of the conditions under which such pronouns are inserted before verbal sentences is raised.

\section{Conclusion}

The present study attempted to examine the nature of transfer of independent subject pronouns from English (L2) into Arabic (L1). Results revealed students' inability to recognize the differences in usage between English and Arabic independent subject pronouns; their inability to examine the syntactic contexts and the pragmatic and discoursal conditions under which independent subject pronouns are used in Arabic.

The syntactic contexts in which the deviant independent subject pronouns occurred and the strategies used to impose independent subject pronouns showed that the subjects lack mastery of the following grammatical rules: Using an independent pro-drop structure in compound sentences consisting of verbal clauses not nominal clauses, as the former case requires a parallel structure, especially in declarative verbal sentences that require subject pro-drop. The error data also revealed translation students' inadequate competence in Arabic 
as they failed to recognize the pragmatic and discoursal conditions under which independent subject pronouns are used.

Mastery of independent subject pronoun use in English-Arabic translation can be achieved by improving translation instruction. Special Arabic language courses for translation purposes should be offered. Such courses should focus on the syntactic functions of Arabic pronouns, the pragmatic and stylistic conditions that determine the use of independent subject pronouns. They should focus on a contrastive analysis of English and Arabic subject pronoun distribution and usage, when Arabic subject pronouns should be dropped, with examples of similarities and differences and increasing students' awareness of the pragmatic, discoursal and syntactic constraints in translating English pronouns into Arabic.

Comparisons of the sources and causes of deviant independent subject pronouns by beginning and advance translation students need to be investigated by future translation research. Analysis of independent pronouns errors as a copula in the translation of English texts into Arabic is still open for further investigation.

\section{Notes:}

In the transcription of Arabic words, th = voiceless dento-alveolar fricative; $\mathrm{dh}=$ voiced dento-alveolar fricative; $\mathrm{S}=$ voiceless palato-alveolar sulcal fricative; $\mathrm{H}=$ voiceless pharyngeal fricative; $\mathrm{D}=$ =voiced dento-alveolar emphatic plosive; $\mathrm{T}=$ voiceless dento-alveolar emphatic plosive; $\mathrm{S}=$ voiceless dento-alveolar sulcal emphatic fricative; $\mathrm{DH}=$ voiced dento-alveolar sulcal emphatic fricative; $\mathrm{G}=$ =voiced uvular fricative; $\mathrm{x}=$ voiceless uvular fricative.

\section{References}


Anton-Mendez, Ines (2010). Gender bender: Gender errors in L2 pronoun production. Journal of Psycholinguistic Research, 39, 2, 119-139.

Arabski, J. (1979). Contrastive studies and interlanguage. Papers and Studies in Contrastive Linguistics, 10, 135-143.

Godin, Louise (1982). A practical application of a study of errors of college Francophone students learning English. ERIC Document Reproduction Service No. ED214374

Iliescu, Sanda M. (1972). Three ways to say "you" among other pronouns. ERIC Document Reproduction Service No. ED109913.

Künzli, Alexander (2009). Address pronouns as a problem in French-Swedish translation and translation revision. Babel; 55, 4, 364-380.

Leonard, L. (1989). Language learnability and specific language impairment in children. Applied Psycholinguistics 10, 179-202.

Montalbetti, M. (1984). After binding. Unpublished doctoral dissertation. MIT.

Moore, Mary Evelyn (2001). Third person pronoun errors by children with and without language impairment. Journal of Communication Disorders, 34, 3, 207-228.

Noor, Hashim H. (1996). English syntactic errors by Arabic speaking learners: Reviewed. ERIC Document Reproduction service No. ED423660. 
Rispoli, M. (2005). When children reach beyond their grasp: Why some children make pronoun case errors and others don't. Journal of Child Language, 32, 1, 93-116.

Rispoli, M. (1998a). Patterns of pronoun case error. Journal of Child Language 25, 533-554.

Rispoli, M. (1998b). Me and my: two different patterns of pronoun case errors. Journal of Speech, Language, and Hearing Research, 41, 385-393.

Rispoli, M. (1994). Pronoun case overextensions and paradigm building. Journal of Child Language 21, 157-172.

Rothman, Jason (2009). Pragmatic deficits with syntactic consequences: L2 pronominal subjects and the syntax-pragmatics interface. Journal of Pragmatics; 41, 5, 951-973.

Ryding, Karin C. (2005). A reference grammar of modern standard Arabic. Cambridge University Press.

Sorace, Antonella \& Serratrice, Ludovica (2009). Internal and external interfaces in bilingual language development: Beyond structural overlap. International Journal of Bilingualism; 13, 2, $195-210$.

Steckol, K. and Leonard, L. (1979). The use of grammatical morphemes by normal and language-impaired children. Journal of Communication Disorders, 12, 291-301. 
Tadros, A. A. (1979). Arabic interference in the written English of Sudanese students-relativisation. English Language Teaching Journal, 33, 3, 234-38.

Yuan, Boping \& Zhao, Yang (2005). Resumptive pronouns in English-Chinese and ArabicChinese interlanguages. International Review of Applied Linguistics in Language Teaching (IRAL), 43, 3, 219-237. 